\title{
Stylistic Foregrounding in The Socio-Political Commentary of Selected Guardian Cartoons
}

\author{
Omolade Bamigboye \& Samuel Adebayo Omotunde \\ douglas_e4@yahoo.com, adebayoomotunde50@gmail.com \\ Department of English and Literary Studies, Ekiti State University, Nigeria
}

\begin{abstract}
The paper investigates the role of textual foregrounding in the understanding of cartoons in The Guardian, a Nigerian daily newspaper. To achieve this aim, Bally's stylistics of humor is used as theoretical basis. Bally's theory claims that there is a connection between language and the thoughts and feelings of its user. It also espouses the idea that as human beings, we respond emotionally in one way or the other to how a language is crafted in a particular context and by a particular user. This is especially the case for structures that are deemed humorous. Using a purposive data selection method, selected cartoon pieces from The Guardian about the 2015 general elections in Nigeria were collated, with a view to subjecting them to stylistic investigation. The eight selected cartoons are analyzed methodically, bringing out the stylistic use of foregrounding by the cartoonists. Findings reveal that through a shared body of world knowledge and current affairs, the cartoonist and his audience communicate via the short, witty and didactic cartoons in the overall interest of probity, decency, and accountability in the Nigerian public place. The artist highlights sensitive information he wishes to emphasize, by bringing such to the fore, through foregrounding. The conclusion and contribution to existing literature is that textual foregrounding, as a stylistic tool, is of immeasurable importance to the cartoonist in the daily execution of his art
\end{abstract}

Keywords: cartoon, foregrounding, stylistics, humour

\section{Introduction}

It will not be trite to say that the cartoon page has now become a popular section readers daily look forward to on the pages of newspapers, newsmagazines, periodicals and the like. For moments given to savoring short, crisp and sarcastic bites on socio-political events in the country, cartoonists have consistently made the day of the average Nigerian newsreader. Their art is delivered in pictorial representations of persons or their acts that are somehow veiled and inferred, perhaps for the purpose of avoiding libelous litigations. Indeed, Jegede (1999, p. 183) captures the whole business of cartooning as 'a conundrum, a graphic phantom that does not always signify what it implies, a medium that at once affirms and denies. It possesses pictorial qualities that facilitate the codification of messages in the succinct, subtle or hidden form'. No doubt, this gives the cartoonist and his craft a special place in the constant conflict between the rulers and the ruled- a voice that is far-reaching and at the same time difficult to silence, especially in a third world country like Nigeria.

The history of political cartoons, especially in the Nigerian context, is rich with memorable episodes that caught both local and national attention, as far as politics and the Nigerian society are concerned. It is replete with the sarcastic castigation and polite denigration of many a political gladiator or the archetypal Nigerian 'big man'. The fact that 
politics (whether progressive or conservative) is an important part of Nigerian life explains the reason it constitutes the major focus on most cartoon sketches in the Guardian newspaper. Guardian cartoonists have over the years routinely satirized, castigated and admonished politicians and indeed the Nigerian public on the negative consequences of politics played not according to the rules of the game and official government policies that are not well-thought-out. The implication, therefore, is that apart from the humor inherent in the sketchy satires of the cartoonist, he inadvertently plays the role of a social crusader and reformer with a view to influencing the state and its agents in the implementation of the social contract it has with the people.

Cartoons are similar to caricature in a way. According to Obasi (2011), cartoons are drawings or a series of drawings that usually tell stories or express messages. Also, Safra and Yeshuan (2007) describe the relationship between caricature and cartoons as using the same artistic medium, particularly to satire perceived ills in society. The editorial cartoon is purposely enacted to relay a part of the opinion of the newspaper for a particular day. In other words, it is used primarily to illustrate the editorial opinion for the day. This is the case through which the expression 'Editorial Cartoon' was derived. However, some cartoons usually appear on the front pages, inner pages or the back pages of various newspapers and magazines. These types of cartoons range from the strips to the pleasure type. Ordinarily, much seriousness is not given to these other types of cartoons by the discerning public. They are mostly meant for entertainment purposes, in contrast to editorial cartoons which serve as a humorous form of conveying important editorial messages to the reading public. The distinction between the editorial cartoon on the one hand, and the rest on the other is, therefore, that of authorial purpose. Editorial cartoons are not meant to be glossed over. Rather, they are presented to either make the reader reason along a particular line, admonish the reader to change or deviate from a particular course, or to stir the reader to perform a particular action. The understanding of these editorial purposes, however, lies in the manner the cartoonist has presented his art to his reader.

Cartoons cannot be removed from the socio-political contexts in which they are produced, (Adeniran, 1984; Nnimo, 1984; Alimi, 1986; Olufemi, 1999; Okoabah, 2000). In other words, both the cartoonist and his audience must share some certain level of mutual contextual beliefs or some background knowledge that is taken for granted. This underground information which is known to both the cartoonist and his audience makes it possible for them to understand each other. It is not unusual not to make sense of a cartoon which the surrounding socio-cultural or political context is unfamiliar to the reader. Mostly, cartoonists use current affairs or issues that have broad appeals with the public as the subject of their cartoons, Olaniyan (1998). They deliberately act on issue78s that are not stale, (Emezue, 2012). Editorial cartoons, in particular, are often times tied to the prevailing news of the moment which also constitute the subject of editorial opinions. Statements and insinuations that may later warrant prosecution or even persecution are routinely made by cartoonists with less anticipation of political or legal backlash from the objects of their satiric innuendoes, who are usually rich and powerful citizens.

Cartooning as an art form and sociocultural expression remains a valid means of collating a people's life experiences, as well as engineering for them an acceptable social mode through constructive criticisms and applause (Medubi, 2008). Indeed, leafing through the various editorial cartoons of The Guardian newspaper between August 2014 and August 2016 presents detailed chronological documentation of the events leading to the successful conduct of the 2015 general elections in Nigeria and its immediate aftermath. In all its depictions and portrayals, the major purpose, one could infer, of this particular editorial cartoons is to present the Nigerian socio-political situations in a rather comical manner with an underlying attempt to critique, criticize, and ridicule the shortcomings of both the politicians and the electorate. It also seeks to re-orientate the reader about the values of honesty in leadership, probity in public office and a 
communal feeling of unity and togetherness among the vast and diverse peoples and regions of the Nigerian state.

Over the years and in the chequered history of the nation, Nigerian cartoonists have used their cartoons to fight colonialism, military despotism, and such other vices in their usual sarcastic manner, (Nwangwu, 1984; Jimoh, 2010). The English language has transformed from being a mere colonial legacy to a sustainable lingua franca that holds the various ethnic groups in Nigeria together, at least linguistically speaking. It also serves as the major language as far as print and electronic modes of communication are concerned. It is, therefore, not a surprise that most cartoonists make use of English in their daily editorial reprimands and admonitions, with the frequent inclusion of linguistic elements from particular indigenous languages and English words and expressions that have over the years been nativized.

The style of cartoon presentation is another important aspect of the art. Some cartoonists favor the use of pictorial representation that graphically communicates the intended message to the reader, while some others fancy the conversational style that involves characters who represent particular segments of the society in which the artist lives, or of whom his art is talking about. Other semiotic or stylistic elements are employed to adequately add substance and enhance meaning, as far as the particular style or model of artistic presentation the cartoonist chooses is concerned, Jewell (2016). Also, Alimi (1991) observes that cartoons can be stylistically studied and evaluated based on the printing styles, registers, and textual features that abound therein; her argument focusing on the artistic mixture of both graphical and textual properties in the achievement of a 'social satire' of the peculiar Nigerian situation, (Alimi 1991, p. 190). Among the findings in Alimi's work is the submission that humor is sometimes contextualized; that is, the reader must infer clues of authorial intent both from the drawings and the text. Alimi concludes that its informal style (which is exemplified by the occurrence of the Nigerian Pidgin English, colloquial forms, loan blends, ellipsis, and telegraphic sentences) characterizes the language of the cartoons in major Nigerian newspapers.

In a nutshell, the style of depiction of editorial cartoons, whether conversational (involving dialogue between at least two people) or picturesque techniques, together with the macro and micro-linguistic features of the language used, goes a long way in the proper understanding of the message the editorial cartoonist seeks to pass across to the reader. Although, like any piece of writing, the meaning inferred from cartoon sketches may be subjective as particular readers may get ambiguous meanings from the coded messages inherent in the cartoons. The subsequent topics in this article will shed more light on the application of some textual resources to the art of the cartoonist, vis-à-vis the subjects of stylistics and humor.

The aim of this study is to investigate the application of foregrounding as a stylistic tool in the depiction of editorial cartoons of the Guardian newspaper and the understanding of the same by the reader. The objectives of why and how foregrounding is used in the conveyance of the underlying cryptic message of these cartoons, even beyond their humorous physical realizations, both constitute the pivots upon which this article is based.

\section{Theoretical Background}

The scientific study of style is technically known as stylistics. Now authorial style differs as a result of so many factors ranging from the author's background, the disposition to social issues, temperament, worldview, the genre he writes in, and so on. In other words, the way a piece of writing comes to be is dependent on all these variables and so many more. An author's style of writing, like any other human activity, is factored on variables which make him the artist that he is, Bamigboye (2016). Also, stylistics studies authorial style from different perspectives. These perspectives include the notions of style as personality, style as choice among various alternatives, style as deviation from the linguistic norm, style as a relationship between content and form, and so on. Although all these perspectives have their strong and weak 
points as well as relevance or otherwise to in particular stylistic investigations, the perspectives from which this paper draws its power are those of style as choice and style as deviation, respectively. The reason for this is that both choice and deviation account for the stylistic value known as foregrounding.

Stylistics as a field of study has the concept of foregrounding as one of its major features. Simply put, linguistic foregrounding is the writer's act of deliberately aiding readerunderstanding by marking particular words and expressions different from the rest of the text. It is known as the feature of linguistic highlighting, where some textual elements are presented in unusual or different manners that will naturally draw the attention of the reader. The purpose of foregrounding has been deemed to aid proper understanding of a text or to determine the real semantic intentions of the writer or artist. When words or phrases and sentences appear differently (maybe in terms of color, font, size, or character) in a text, the attention they draw is stylistically relevant. It is an attempt by the writer to mean that they should be paid more attention so as to get his actual message. It is a way the writer leads the reader on, in the quest for textual clarity.

Scholars in the field of style and stylistics have labeled foregrounding as the phenomenon of linguistic highlighting (Halliday 1971; Simpson; 2004, Leech and Short, 2007). This departs from Kress and Van Leeuwen's (2006) description of foregrounding as having to do with multimodal features of colors, images, drawings and the rest. Both Kress and Van Leeuwen are more concerned about the interpretative tendencies of the aforementioned variables than in the actual linguistic text. Mills (1995, p. 176) refers to it as the positioning of an element in a prominent place in a text which it does not usually occupy, thus drawing attention to it'; while to Wales (2001, p. 157), foregrounding means 'throwing into relief of the linguistic sign against the background of the norms of ordinary language' i.e introducing a different paradigm against an already established one in the general graphological and orthographical layout of a particular passage or text. Indeed this particular stylistic effect is not uncommon in the works of great writers. They have successfully used foregrounding in the dissemination of their authorial meanings over the years. The purposive and intentional use of this stylistic device makes it a fundamental issue in both historical and contemporary stylistics study. The fact that foregrounding can reflect in the textual spread at the phonological, lexico-semantic, graphological and syntactic levels of language description, is a testament to its indispensability in the study of authorial style. Although the frequency or degree to which particular authors foreground sensitive aspects of their works differ from one another, it nevertheless still forms a substantial part of many stylistic interpretations of texts.

Bally's stylistics of humor comes readily available and attractive for this kind of stylistic analysis. Bally (1909) theorized on the subject of stylistics and its application to humor in an elaborate and easily applicable way. According to Bally and as quoted in Attardo (1994, p. 231), stylistics is 'a branch of psychology which studies the correlations between language, on the one hand, and thoughts and feelings (sentiments) on the other' (Bally, 1909 p. 5-7). This relationship accounts for the reader or hearer response(s) to what is read or heard. In other words, we respond emotionally in one way or the other to how a language is used by a particular user. This is especially the case for structures that are deemed humorous.

Bally also discussed the social function of stylistics as it studies the 'affective value' of the facts of language. The dexterity or competence of a writer compelling his reader to add emotional value to facts and objective description of reality. In depicting reality through his art, therefore, the artist/writer/cartoonist lays bare the content which is interpreted by the reader. The reader does this interpretation not only with the objective (linguistic) acumen or competence he has, but with added social feeling or emotion attached to it. The argument really is on the reader-reaction to what is written and the way it is written. This emotive aspect of stylistic description informs the notion that 'any linguistic information embodies in part, the language and in part, aspects of the man who interprets or announces the information' 
(Nnadi, 2010 p. 29). So, emotional (approving or disapproving) reading of texts is a direct effect of a writer's linguistic dexterity and constitutes the central idea inexpressive stylistics, as espoused by the French linguist, Charles Bally (1909).

\section{Methods}

Through a purposive selection method, eight cartoon pieces authored by both Obe Ess and Emanuel Onu, were selected from The Guardian newspaper. These eight are replete with textual foregrounding and other graphological illustrations required for this study. They also contain thematic contents that bother on the socio-political situation of Nigeria towards and immediately after the 2015 general elections. All these adequately satisfy the demands of the present study as is well stated in the sections above.

The sketches of cartoon collated for this study are purposively selected because they are replete with textual foregrounding as they run commentaries on the socio-political situation of present-day Nigeria. The justification for the collation of these particular cartoons lies in the knowledge that they satisfy the authorial inquest into deployment of foregrounding as a stylistic tool by cartoon artists in their daily strive to run commentaries, pass judgment, satirise human foibles and generally seek an improvement in the way and manner Nigerians, both public office holders and citizens alike, conduct themselves in manners that edify the country. It should be noted that in the run-up to the Nigerian elections of 2015 and its immediate aftermath, most of the editorial cartoons of The Guardian were authored by Obe Ess. This subsequently accounts for the preponderance of his works over that of D. D. Onu.

The procedure employed for the evaluation of the selected cartoons involves a careful study of each at the graphological level of stylistic analysis, which Bamigboye (2016) refers to aesthetic patterns of written language; the shape of language on the page. Although words, expressions, graphetic symbols, unusual fonts, pictorial distortions and other textual abnormalities that call attention to themselves could be used stylistically (at the graphological level only, being the central concern of this paper), bringing out possible authorial intents behind their deployments and the possible stylistic effects they might have on the reader; however, not all stylistic features are mandatory to be employed in particular texts.

Each cartoon piece is numbered and the stylistic element(s) of lexical choice and/or textual highlighting (foregrounding) examined one after the other. The stylistic questions of 'why' and 'how' certain choices are made by language users constitute the bases of the intellectual inquiry into the eight selected cartoon pieces.

\section{Results and Discussion}

The stylistic investigation into how foregrounding has helped the successful delivery of the cartoonists' art in the selected pieces helped us to register the following results. In this section, we shall discuss the results of the stylistic investigation into how foregrounding has helped the successful delivery of the cartoonists' art in the selected pieces. Also, an overview of the eight cartoons reveals that the most prominent form of stylistic foregrounding employed by the cartoonists is the use of bold fonts, capitalisations, inverted commas, (substituted) acronyms and ellipsis.

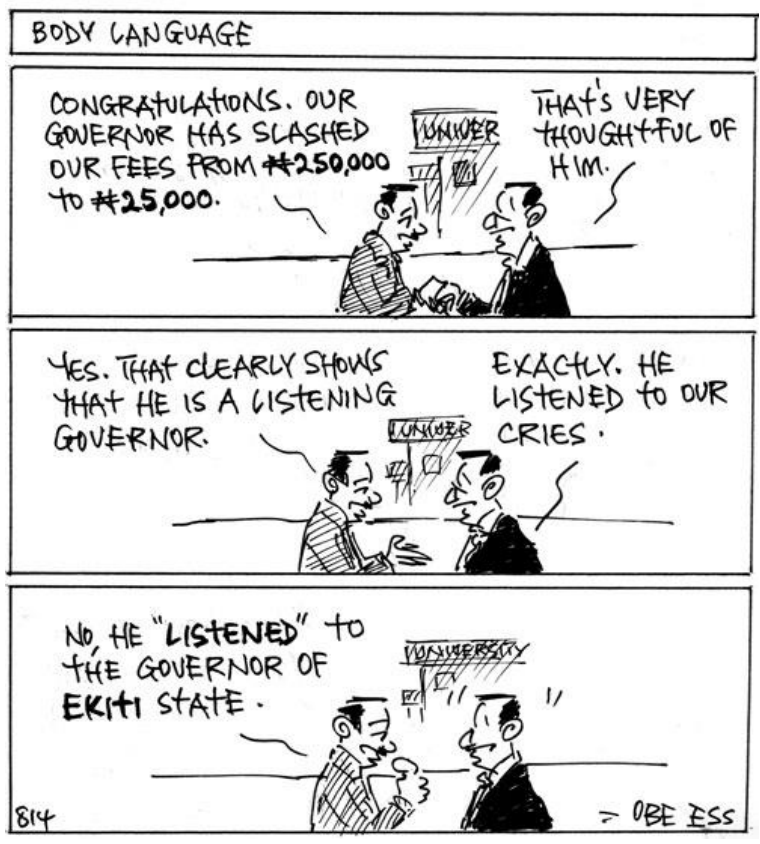

Figure 1. Obe, O. (2014, August 8). 'Body Language'. The Guardian, p. 8. 
Figure 1, created shortly after the Ekiti State Gubernatorial elections held, show the style with which the cartoonist captures Former Governor Fayemi's loss and the reversal of the exorbitant increase of the fees of Lagos State University students by the then Governor Babatunde Fashola. Aptly titled "Body Language", the cartoonist foregrounds the word 'listened' to make an inference as to the (possible) reason Governor Fashola rescinded the somewhat draconian decision. The graphological use of the inverted commas attests to this. Perhaps, it is to guard against his party suffering a similar electoral defeat as they did in Ekiti. Something one can infer from this particular cartoon is the way politicians read the electorate and try to mitigate political misfortune by dancing to the tunes of aggrieved voters, especially when elections are near.

Change, the campaign slogan of the ruling All Progressives Congress (APC) and the mantra through which it won the 2015 presidential elections, is foregrounded in Figure 2. Titled "The wind of change," it is somehow obvious that the desired results of the change have not been largely felt by the citizenry, judging by the visa applicant's economic reason for wishing to immigrate to America.

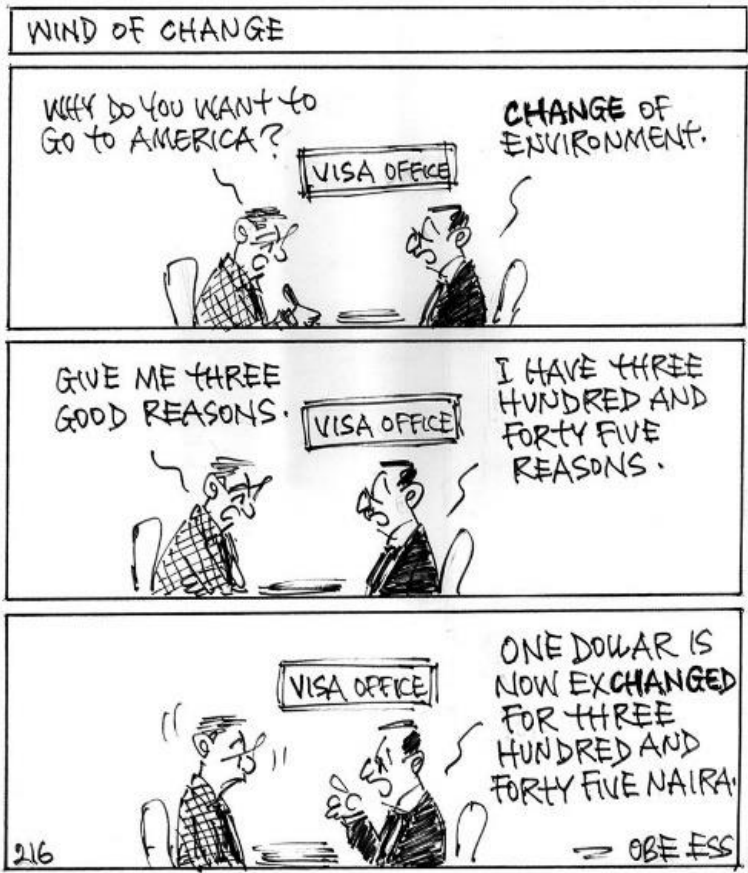

Figure 2. Obe, O. (2016, February 19).'Wind of Change'. The Guardian, p. 10.
The economically debilitating Naira (Nigerian currency) to Dollar (American currency) exchange-rate has taken its toll on many a Nigerian middle class family, prompting the panic exodus of thousands to other more viable shores. So, according to the cartoonist, instead of the expected and desired political cum economic 'change', what Nigerians received was the astronomical currency exchange-rate.

A militant group operating in the creeks of the Niger-Delta region of Nigeria is worryingly named the Niger-Delta Avengers (NSA). Apart from avenging the alleged years of rot and neglect of their region by successive governments through the illegal refining of crude, it also plans to cripple the Nigerian economy by consistently blowing up oil installations across the length and breadth of the country. In Figure 3, the police officer questioning the suspect in the cartoon above accuses him of being a member of the dreaded militant group. He (the accused) replies by saying that he was only scavenging the dumpsite close to the oil pipeline because he was hungry.

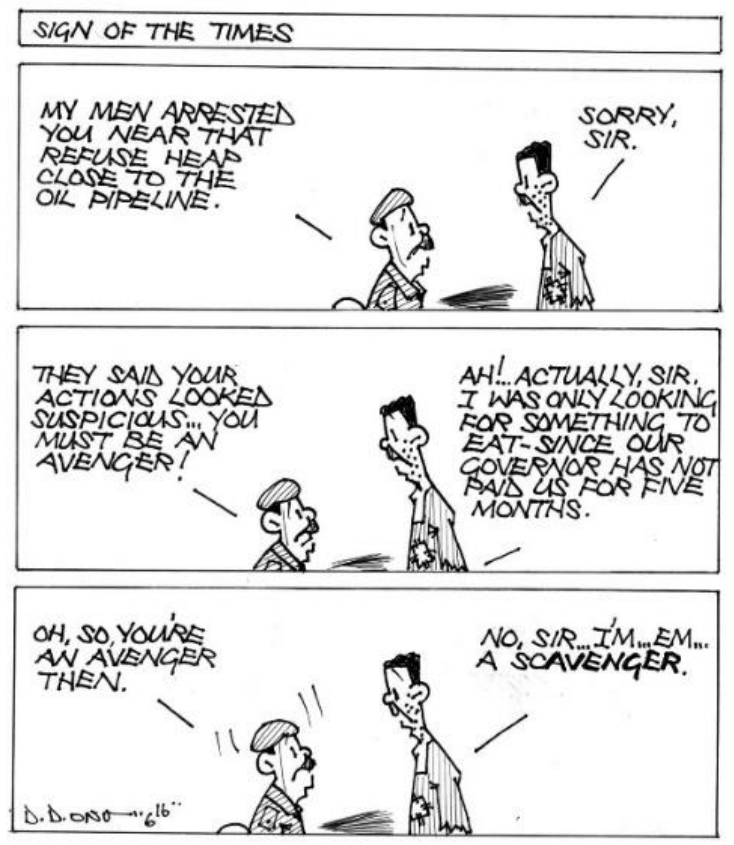

Figure 3. Onu, D. E. (2016, June 18).'Sign of the Times'. The Guardian, p. 8.

Thus, through sarcasm, the cartoonist brings to the fore the economic hardship afflicting the average Nigerian occasioned by 
months of unpaid salary. Also, he unwittingly challenges the state to do more about the welfare of the citizens the same way it has faced the militants.

The metaphor of the ephemeral nature and ultimate ignominious end awaiting those who benefit from quick or easy money is well illustrated in Fig. 4.

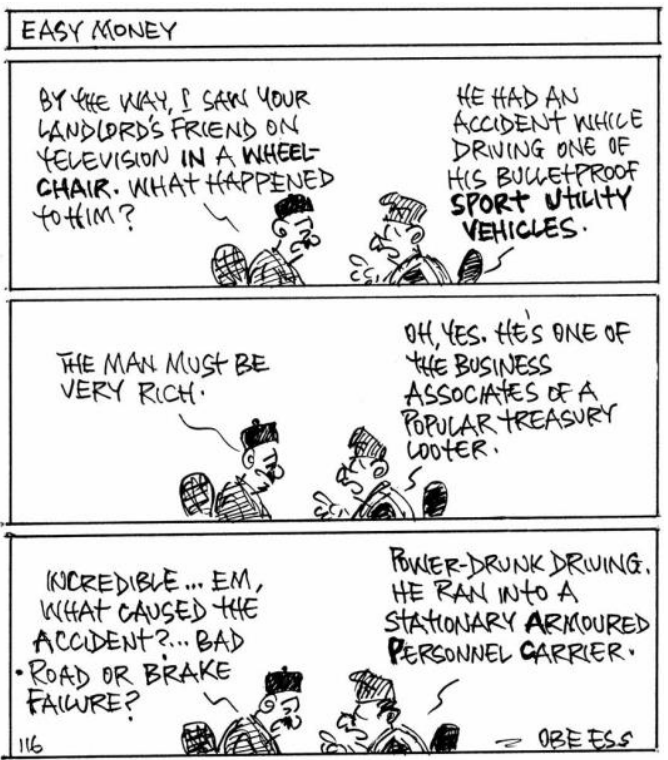

Figure 4. Obe, O. (2016, January 18).'Easy Money'. The Guardian, p.8.

All Progressives Congress (APC), the political party which produced the government that has now become the nemesis of many corrupt politicians of the old order, is substituted for an Armoured Personnel Carrier, a military vehicle which is designed to crush any unwanted thing or object of resistance in its path. This comparison is made by the foregrounding of the initial letters of the military-built vehicle, APC. Also, the opposition Peoples' Democratic Party has its acronym read Power Drunk-Driving. The two ellipses in the stutter of the interlocutor jocularly suggest the mutual contempt between the Nigerian poor and the extremely rich. Consequently, the object of discourse in the conversation of the two interlocutors in this particular cartoon has met his waterloo in the process of enjoying his ill-gotten wealth.

In the next cartoon (see Fig. 5), the parody of the scandal involving at least two politicians in the run-up to the 2015 general elections is not lost on the discerning reader.

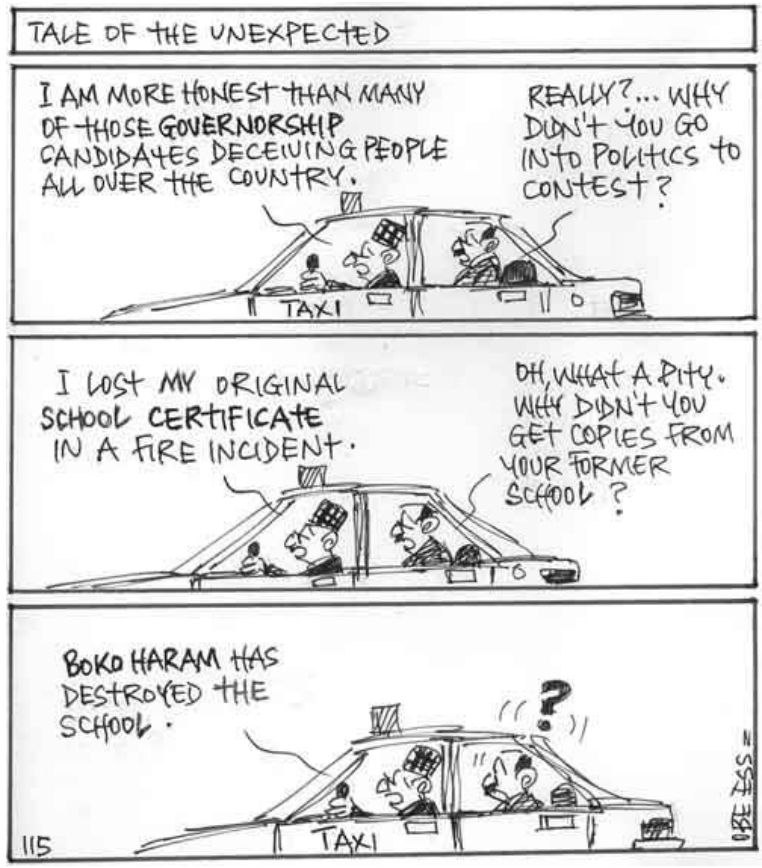

Figure 5: Obe, 0. (2015, January 22).'Tale of the Unexpected'. The Guardian, p. 8.

When the Nigerian Army said it could not lay hands on the certificates of Gen. Muhammadu Buhari, the then presidential candidate of the All Progressives Congress, the whole country was concerned and the issue generated much of debate in both orthodox and unorthodox media. Particular expressions are made bold so that the message of dishonesty in the conduct of politicians is not lost on the reader. This could also be seen in the overtly big and darkened question mark above the taxi customer which addresses the puzzled countenance of many Nigerian citizens to the way politicians tell lies unabashedly. Again, the use of ellipsis signifies that the customer deliberately pauses and then engages the driver in a dialogue. This is particularly humorous when read against the Nigerian socio-cultural context of negative reactions to self-praise.

Former President Goodluck Jonathan's first name is played upon in Figure 6. 


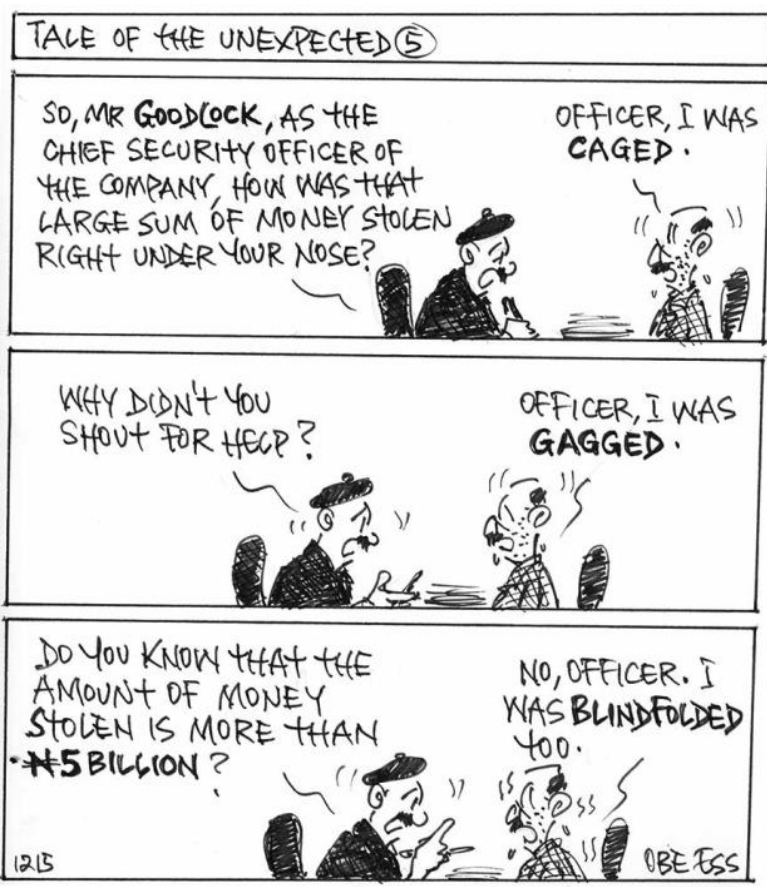

Figure 6. Obe, 0. (2015, December 14).'Tale of the Unexpected (5)'. The Guardian, p. 10.

The 'luck' in Goodluck is changed to 'lock', which refers to an appliance used to secure property. Money running into billions was allegedly siphoned from the public coffers using the purchase of military hardware as conduit pipe. The foregrounding of the words caged, gagged and blindfolded suggests the seeming helplessness or lethargy on the path of the former President in overseeing and manning the nation's treasury. Whereas a very good lock is supposed to serve the purpose of safeguarding one's property against burglary, this particular lock has failed in that responsibility. Also, the sweat of perspiration continuously dropping from the accused shows his exasperation and helplessness.

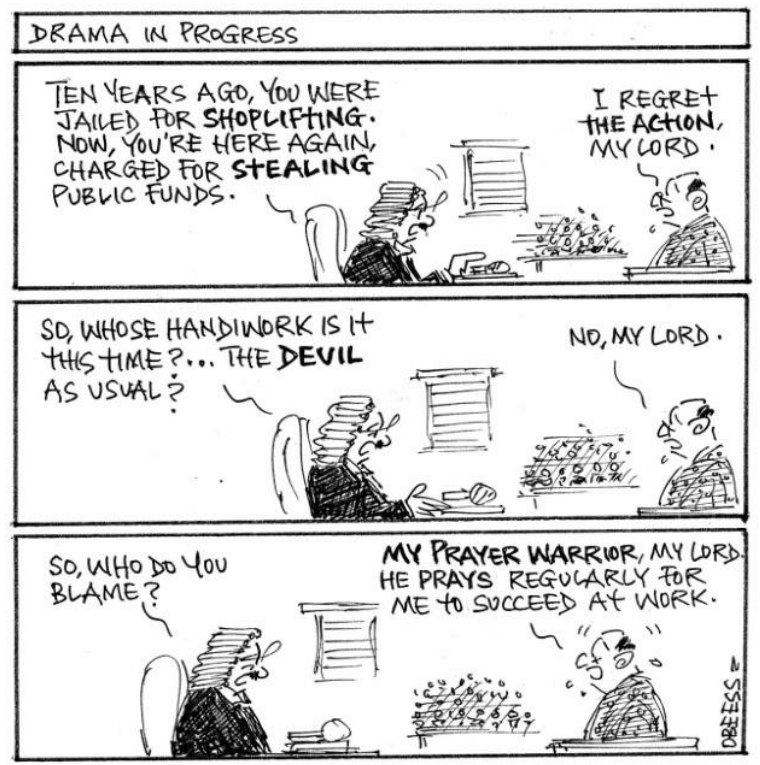

Figure 7. Obe, O. (2016, May 2) 'Drama in Progress'. The Guardian, p. 10.

In this editorial cartoon, the use of ellipsis calls the reader's attention to the hypocritical nature of some Nigerians who shelve responsibility for wrongdoing to metaphysical entities. It reflects the judge's exasperation. The gradual moral deterioration from petty 'shoplifting' to 'stealing public funds' is also significant. The 'action', a euphemistic colouration of corruption, is only blamed on the accused person's 'prayer warriors' who indulge many politicians.

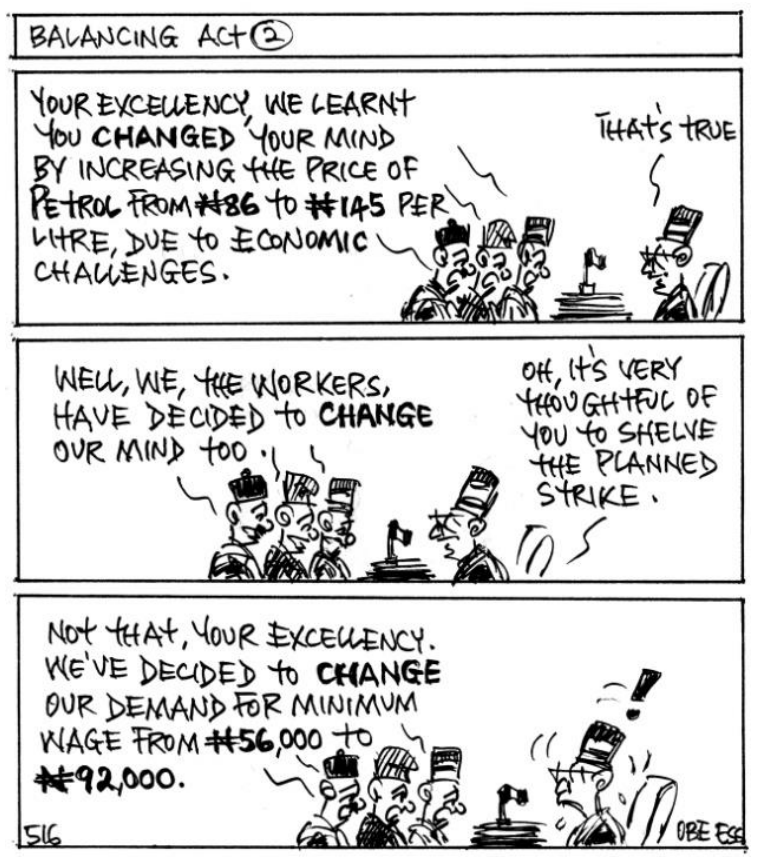

Figure 8. Obe, 0. (2016, June 12). 'Balancing Act

(2)'. The Guardian, p. 12 
In the piece above, the political office holder is stunned by the labor leaders' negotiating skills. This much is graphically captured by the huge blackened exclamatory mark above the bureaucrat. What this demonstrates is that the reader's attention drift will definitely be caught by the foregrounded elements in the understanding of the piece.

The findings in all eight analyses, which are in direct correspondence to the specific objectives of the research, have validated earlier submissions on the incontrovertible nature of the concept of foregrounding as a stylistic tool. The stylistic use of graphologically significant tools (ellipsis, fonting, bold prints, and exclamatory marks) helps the reader to focus on the meaningmaking mechanisms the cartoonist incorporates into his art. Although the drawings are the hallmark of this genre, this academic effort, however, focuses on the stylistic features of the text as contributing to the meaning of the cartoons. This is aptly demonstrated by the sheer deployment of these linguistic resources as complementary accessories in the overall business of making sense through cartooning.

Stylistics, being a bridge between linguistics and literature, requires a degree of subjectivity in its analysis. This is why stylisticians are often referred to as linguistic critics. The analysis that has been provided here, although done based on the theoretical foundation of stylistics of humor as bringing emotions to bear on graphics, nevertheless underscores the researcher's understanding of the core principle of stylistics as a scientific study and its analysis an inexhaustible one. Going by these assertions therefore, the results can claim to be justified on the strength of its commitment to the principles and foundations set out at the beginning of this academic exercise. The theoretical appreciation of foregrounding is further enhanced as well as the application of the tenets of stylistics to any kind of text. In a nutshell, the results are in consonance with the hypothesis put forward earlier and resonate widely with the theoretical foundations upon which the concept of linguistic foregrounding was developed.

\section{Conclusion}

Going through the analyzed pieces of cartoon, the role stylistic foregrounding plays in the eight excerpts is that of adding to the process of making sense to what the cartoonist says. Foregrounding is used to point the reader's attention to particular words and expressions which ordinarily should trigger a whole lot of condensed information about the current affairs of the country which are stored in the residual memories of people. The cartoonist plays on these particular linguistic features by guiding the reader's eyes and inadvertently his mind to the real semantic intentions behind the deployment of the stylistic tool known as foregrounding. This finding goes a long way to contribute to the already vast literature on cartoonists and their art. Although foregrounding is a major concept in stylistics, there is no doubt that the purpose of any stylistic study such as this could be better served if other stylistic features are also studied therein. This seeming limitation can, however, be addressed by subsequent researchers in the field of stylistics.

\section{References}

Adeniran, S. (1984). An appraisal of Concord newspaper Cartoons (Unpublished B.A Thesis), Obafemi Awolowo University, IleIfe, Nigeria.

Akinfeleye, R.A. (2008). Health and behavioural change communication for development.Ibadan, Nigeria: Spectrum Books Ltd.

Alimi, M. M. (1986).Communicating through cartoons: A psycholinguistic study of the language of cartoons in some Nigerian newspapers (Unpublished Doctoral dissertation), University of Ibadan, Nigeria.

Alimi, M. M. (1991). A study of the stylistic markers of language of cartoons in Nigeria. In Studies in African Linguistics, 22 (2), 189-206. 
Attardo, S. (1994).Linguistic theories of humour. Berlin: Mouton De Gruyter.

Bally, C. (1909). Traite de Stylistique Francaise[Treatise on French Stylistics]. Heidelberg, Baden- Wurttemberg, Germany: Winter.

Bamigboye, O. (2016). A comparative graphostylistic analysis of Adichie's Half of $A$ Yellow Sun and Mantel's Bring Up The Bodies. In O. Adebowale, T. Olumuyiwa \& $\mathrm{B}$, Oshodi (Eds), Inquiry in African Languages and Literatures (pp. 20-30). Akungba, Ondo, Nigeria: Adekunle Ajasin University Press.

Bamigboye, O. (2016). A comparative study of style in Adichie's Half of A Yellow Sun and Mantel's Bring Up The Bodies (Unpublished Doctoral Dissertation). Ekiti State University, Ekiti, Nigeria.

Emezue, I. N. (2012). A Pragma-Sociolinguistic Interpretation of Cartoons as Visio-Verbal Communication. In Proceedings of the6th World Congress on Communication and Arts(pp. 17-22). Geelong: WCCA.

Halliday, M.A.K. (1971). Linguistic function and literary style: An inquiry into the language of William Golding's The Inheritors. In S. Chatman (Ed.), Literary Style: A symposium (pp. 330-365). New York: Oxford University Press.

Jegede, D. (1999). Nigerian cartoonists: Sleeping with one eye open. In O. Tunji (Ed.), The Media Transition and Nigeria (pp. 16-28). Lagos: Tosen Consult.

Jewell, K. W. (2016). Hidden in plain sight: Image, text, and social commentary in Victor Ekpuk's cartoons for The Daily Times of Nigeria, 1989-1998. Retrieved from

http//www.scholarscompass.vcu.edu/et d/4194

Jimoh, G. A. (2010) The Role of Editorial Cartoons in the Democratisation Process in Nigeria: A Study of Selected Works of Three Nigerian Cartoonists (Unpublished Master's Thesis), University of Lagos, Lagos, Nigeria.

Kress, G., \& van Leeuwen, T. (2006). Reading Images. London: Routledge.
Leech, G.N.,\& Short, M.H. (2007). Style in fiction: A linguistic guide to English fictional prose. London: Pearson Education Limited.

Medubi, O. (2008). Cartooning in Nigeria: Large canvas, Little movement'. In J. A. Lent (Ed.), Cartooning in Africa(pp. 197214). New York: Hampton Press.

Mills, S. (1995). Feminist stylistics. New-York: Routledge.

Nwangwu, C. (1984, November 11). Nigeria's graphic warriors. The Guardian, pp. 6, 9.

Obasi, F. (2011). News writing and reporting: A practical approach. Enugu: Alliance Publications Nigeria Limited.

Okoabah, N. (2000). A Socio-semiotic analysis of cartoons in selected Nigerian magazines'. (Unpublished Master's Thesis). University of Ibadan, Nigeria.

Olaniyan, T. (1998). The traditions of cartooning in Nigeria. In Glendora Review: African Quarterly on the Arts, 2(2), 92-103.

Olufemi, A. (1999). A stylistic analysis of the language and message of cartoons in some Nigerian newspapers' (Unpublished Master's Thesis), University of Ibadan, Ibadan, Nigeria.

Nnadi, I. C. (2010). A linguistic stylistic analysis of Chukwuemeka Ike's Novels', (Unpublished Doctoral Dissertation), University of Jos, Jos, Nigeria.

Nnimo, B. (1984, November 11). Are cartoonists people? The Guardian, p.7.

Safra, J. E., \& Yeshuan, H. (2007). Encyclopaedia Britannica (15th ed.). Edinburgh: Encyclopaedia Britannica Incorporation.

Simpson, P. (2004). Stylistics: A resource book for students. New York: Routledge.

Wales, K. (2001). A dictionary of stylistics. London: Longman. 